\title{
Insights from pharmacogenetic studies of antidepressants
}

\author{
Laura Mandelli \\ From $1^{\text {st }}$ International Congress on Neurobiology and Clinical Psychopharmacology and European \\ Psychiatric Association Conference on Treatment Guidance \\ Thessaloniki, Greece. 19-22 November 2009
}

Up to $60 \%$ of depressed patients do not respond completely to antidepressants and up to $30 \%$ do not respond at all. Among the many reasons leading to non-response, such as inadequate treatments and comorbid conditions, genetic factors as likely to contribute to up to $50 \%$ of variance in antidepressant response. Environmental factors, such as chronic stressors, psychosocial adjustment and personality traits may also influence response to treatment and interact with these. The investigation of both of these types of factors has been informative in genetic aetiological studies (e.g. Caspi et al., 2003) and is increasingly employed in pharmacogenetics.

A growing number of genetic variants have been replicated in terms of association with SSRI efficacy. They include polymorphisms in the serotonin transporter gene (5-HTTLPR), tryptophan hydroxylase gene (TPH), 5HT1A and 5HT2A receptors, the G-protein beta3subunit (GNB3), Catechol-O-methyltransferase (COMT), the noradrenaline transporter (NAT), and dystrobrevin binding protein 1 (DTNBP1). Data indicating environmental stressors and temperamental traits as moderators of the effect of such genes on response to treatment will also be presented.

In conclusion, there are genetic and environmental factors that interact in a complex manner to impact on response to treatment with antidepressants. Increased understanding of these, including clinical characteristics such as "harm avoidance," may assist the clinician in deciding the best antidepressant to prescribe for a given patient.

Published: 22 April 2010

Institute of Psychiatry, University of Bologna, Italy

\section{References}

1. Mandelli L, Mazza M, Martinotti G, et al: Harm avoidance moderates the influence of serotonin transporter gene variants on treatment outcome in bipolar patients. I Affect Disord

2. Mandelli L, Marino E, Pirovano A, Calati R, et al: Interaction between SERTPR and stressful life events on response to antidepressant treatment. Eur Neuropsychopharmacol 2009.

3. Mandelli L, Serretti A, Marino E, et al: Interaction between serotonin transporter gene, catechol-O-methyltransferase gene and stressful life events in mood disorders. Int I Neuropsychopharmacol 2007, 10(4):437-47.

4. Müller DJ, Mandelli L, Serretti $A$, et al: Serotonin transporter gene and adverse life events in adult ADHD. Am J Med Genet B Neuropsychiatr Genet 2008, 147B(8):1461-9.

doi:10.1186/1744-859X-9-S1-S8

Cite this article as: Mandelli: Insights from pharmacogenetic studies of antidepressants. Annals of General Psychiatry 2010 9(Suppl 1):S8.

Submit your next manuscript to BioMed Central and take full advantage of:

- Convenient online submission

- Thorough peer review

- No space constraints or color figure charges

- Immediate publication on acceptance

- Inclusion in PubMed, CAS, Scopus and Google Scholar

- Research which is freely available for redistribution

Submit your manuscript at www.biomedcentral.com/submit 